\title{
Sam's Book as Symbolic Metaphor for Loss
}

\author{
Silvia Kofler \\ 14637 Wyoming Kansas City, Mo 64112, USA \\ Email: Koflersilvia3@gmail.com
}

How to cite this paper: Kofler, S. (2016) Sam's Book as Symbolic Metaphor for Loss. Open Access Library Journal, 3: e3059. http://dx.doi.org/10.4236/oalib.1103059

Received: October 13, 2016

Accepted: November 18, 2016

Published: November 21, 2016

Copyright ( 2016 by author and Open Access Library Inc.

This work is licensed under the Creative

Commons Attribution International

License (CC BY 4.0).

http://creativecommons.org/licenses/by/4.0/

(c) (†) Open Access

\begin{abstract}
The present manuscript aims to explore the attitude and emotion/motivation of the author/agent, David Ray, necessary for the creation of Sam's Book, the creation of his symbolic Metaphor for Loss through a close look at the speaker/agent as defined by Burke within the technical form of the poems. The paper is divided into four sections that give the methods of the analysis in the introduction, give the author's use of language throughout the poems, give examples of the author's memory of events, and in the last and longest section give the author's motivations and the observer/ critic's conclusions about the creation of the poems.
\end{abstract}

\section{Subject Areas}

Literature

\section{Keywords}

Author, Agent, Burke, Expression, Language, Loss, Memory, Metaphor, Speaker, Symbols

\section{Introduction and Explanation of Methods}

"We seek absolution, and writing is a spiritual search, like religion or addiction" states David Ray in his interview with J.F Garmon (5) [1]. Ray as the agent created a collection of poems as a response to the death of his nineteen-year-old son Sam. It is this act, his son's accidental death caused by alcohol that put the author in motion to create this symbolic collection.

The creation of this symbolic metaphor can be defined through Burke's theory of Dramatism because it is the study of language as an act. "The poet steps forth, and his first step is the translation of his original mood into a symbol... and it is precisely this junction of emotion to a technical form which we designate as... 'an idea for a poem"' (Burke, Counter-Statement 56) [2]. Therefore, this exploration will try to attempt to 
explore the attitude and emotion/motivation of the author/agent through a close look at the speaker/agent within the technical form of the poems. Furthermore, this differentia is important because there is a distinction between the author and the speaker in the emotion/attitude displayed in the form of the poems. Burke proposes:

Since there are no forms of art which are not forms of experience outside of art, we may-so far as form is concerned-discuss the single poem or drama as an individuation of formal principles. Each work re-embodies the formal principles in different subject-matter. A "metaphór" is a concept, an abstraction-but a specific metaphor, exemplified by specific images, is an "individuation". Its appeal as form resides in the fact that its particular subject-matter enables the mind to follow a metaphor-process. In this sense we would restore the Platonic relationship between form and matter. A form is a way of experiencing; and such a form is made available in art when, by the use of specific subject-matter, it enables us to experience in this way. (Burke, Counter-Statement 143) [2].

Therefore, for this analysis the Metaphor of Loss is the concept/abstraction, and the specific images portrayed through language in the actual poems is the individual expression/act (different from the act/death that brought about the responsive act) of the author/agent [2]. However, this author/agent and his motives can only be found through the speaker/agent of the form itself.

Consequently, when readers identify themselves with the speaker/agent through the images expressed in language, and they experience similar emotions of loss while reading Sam's Book, they have become consubstantial with the author/agent. "[B]y looking within the structure of these actions, one may find motivation within the structure" (Cohrs 2) [3].

First, in order to take a close look at the speaker/agent through the language in Sam's Book, the symbolic action of the writing of the book needs to be explained through a brief exploration of the author himself. As David Ray states in his interview with Garmon the act of writing in itself is a search (Garmon 5) [1]. So, the poems within the book are images produced during the act of searching for a resolution, for a coming to terms with the loss and guilt.

Many of David Ray's poems deal with his struggle with alcoholism and the survivor's guilt of knowing that he could never have overcome his addiction had his son not been killed in an accident so horrible that Ray accepted as valid a friend's conclusion that if he ever drank again, his grief for his son would get out of bounds and he would kill himself. (Youree 5) [4].

David Ray himself affirms this statement: "If alcohol killed my son, and it did, I can never again have anything to do with it...The waves of grief are farther apart, and with time less intense-most of the time-but grief is never resolved entirely, except perhaps by the very wise, which I'm not" (5) [5]. It is this statement that reveals so much about the ethos of the author/agent, for behind this statement rests the motivation and attitude necessary for the creation of Sam's Book, for the creation of Ray's symbolic Metaphor for Loss [2]. 
It is deplorable, but not tragic, simply to be a victim of circumstance, for there is an important distinction between destiny and sheer victimization. Sheer victimization is not an assertion-and it naturally makes not for vision but for frustration...But, at the moment of tragic vision, the fatal accidents are felt to bear fully upon the act, while the act itself is felt to have summed up the character of he agent. (Burke, Motives 39) [6].

Furthermore, " $t \mathrm{t}]$ ragedy is Burke's favorite way of removing guilt. There are two ways to typically alleviate guilt, victimage and mortification. Victimage is blaming someone else and passing the guilt on to them...Mortification is just accepting the guilt and moving on. It is a more ideal option" (Carpenter) [7]. In this case, the author/agent has accepted it and moves on through the writing of the book. The book becomes an act for catharsis. Secondly, the author/agent is the force behind the actual images in the language of the poems. It is his action that created the symbolic language, and it is his memory. "As for poetics pure and simple: I would take...motivational dimension to involve the sheer exercise of 'symbolicity' (or 'symbolic action')...” (Burke, Language 29) [8]. However, this becomes more complicated because "from the standpoint of Poetics, one should try ideally to work out explanations in terms of the poem as poem" (29-30) [8]. This statement of Burke's brings this analysis to the point where, in place of this introduction, it should have started right away with the actual speaker/agent within the actual images of the language of the poems. However, without the explanation of the context in which the work was conceived this analysis could never refer to the collection as a whole as a Metaphor of Loss, because Burke states that the" symmetry of the pentad requires that...an agent, like an act, must be placed in some scene" (70-1) [8]. Therefore, this introduction is the scene for the act of critical analysis of Sam's Book.

\section{The Authorand Language}

Now, the search for the author/agent, his perceived loss/experience (act) and catharsis within the actual images of language (scene), through the memory of the speaker/agent can begin, because the reader of the poems can only become consubstantial (identify him/herself) with the author/agent through the speaker/poem agent. Furthermore, the reader/critic can only evaluate the actual symbols on the page [8].

[For h] owever important to us is the tiny sliver of reality each of us has experienced firsthand, the whole overall "picture" is but a construct of our symbol systems. To meditate on this fact until one sees its full implications is much like peering over the edge of things into an ultimate abyss. And doubtless that's one reason why, though man is typically the symbol-using animal, he clings to a kind of naive verbal realism that refuses to let him realize the full extent of the role played by symbolicity in his notions of reality. (Burke, From Language 1343) [8].

It appears that humans can only evaluate the verbal realism created from memories of reality, but therein (according to Baudelaire) lies our glory. The inclusion of the following quote from Baudelaire in the introduction to Sam's Book gives the reader/critic a glimpse into the motivation of the author/agent.

"Noir assassin de la Vie et de l'Art, Tu ne tuerasjamaisdans ma mémoire... qui fut- 
monplaisir et ma gloire!" (qtd. in Ray iv). Black assassin of life and art In my memory you will never kill... who was my pleasure and glory! (Translated by Kofler) [9].

It is through memory of the loss in the actual lines of the poems that the reader will identify him/herself (become consubstantial) with the author/agent. It is through the memory of the speaker/agent who emerges from the writing that the memory of the loss will live on. Therefore, through this process of writing the healing of the author/ agent begins.

In this analysis the reader/critic attempts to find the emotions/motivations (the act of the loss) of the author/agent through the observations of the speaker/agent within the particular scenes of the technical form. Furthermore, in the analysis the agent part will be implied and will be referred to simply as speaker and author. Also, consubstantiality will be with the reader. "If, in a work of art, the poet says something, let us say, about a meeting, writes in such a way that we desire to observe that meeting, and then, if he places that meeting before us - that is form. While obviously, that is also the psychology of the audience, since it involves desires and their appeasement" (Burke, Counter-Statement 31) [2].

In Ray's poem "At the Opera” the speaker "sit[s] in the balcony,/next to an empty seat" (1-2) [9]. Here the empty seat symbolizes the loss of Sam. It is an implied metaphor for loss. Furthermore, the speaker observes the unkind treatment of an other child: "Three rows below me a man/slaps at his son,/for the small boy conducts/right along with the maestro /...jumps around/in his seat. I hold myself back,/sink into shadows...(3-8) [9]. The speaker observes this act of a stranger in the audience and is angry, he wants to act, wants to admonish him, but he restrains himself. He disappears into the shadows, and his disappearing can be seen as the author's feelings while writing this scene. Ray no longer has a son, he only remembers him, he like the speaker wishes for "a life I would like/to hear singing, conducting,/with hands I can only see/grabbing at stars, ancient fireflies" (17-20) [9]. At this point the reader can feel the same loss. At least he has an idea what it must be like to lose a child. It is this skill of the author to choose certain images, to choose certain symbols that the speaker expresses, that enable the reader to at least partially identify him/herself with the speaker, and by extension with the author. "Rueckert maintains, [that this] is comparable to Burke's insistence that 'the forms [in this case poems] of language and the forms of self' interinanimate[sic] each other and that 'every kind of structural progression in a verbal work derives its symbolic content from the origins in the life of the creating self and from the functional action of language of the self“ (qtd. in Henderson 3) [10]. The author's motivation may have been to share with readers his appreciation of Sam, his dismay at this stranger who does not appreciate his son. In the reader this metaphor invokes a similar feeling.

Additionally, the scene itself, the opera, is a symbol for drama, for acting out human conflicts. Also, the drama at the opera is heightened. Furthermore, the speaker observes two acts, the act of the man with his son who wants to be the maestro, the master, and the "marriage/of Figaro..." which he observes without his son (12-13) [9]. The speaker, 
like the child, wishes to be the master, wishes to be in control and act in his own drama, but he knows that this is not possible, that he merely grabs at stars. In addition, the fireflies are nocturnal beetles that glow only briefly. So, the author may compare his lost son to them, because Sam like the fireflies only glowed for a brief moment in time. However, the memory of the speaker, through the technical form of the poem, will keep him alive.

\section{The Author and Memory}

In "When My Children Left for the Alps" the speaker expresses his grief and guilt about words spoken, but not heard during a time his son and daughter left without him. And, like the speaker in "At the Opera" the speaker expresses himself in first person.

Having so little, I could give them just this-their first words, which I still held in mind, his "Help me!" as he waddled in diapers, trying a doorknob, in Spain, my Sam-son, on that island together. And hers, "Where'd he go?" called out when a dog ran from her as she sat in a cardboard box on the floor and I stooped to shove her along. Now they have gone to cold mountains, I felt it then, feel it now... in the blinding snow... maybe they heard behind them my call, "Love Dad" (1-11, 15-16) [9].

The speaker, through memory, finds himself in several scenes in this poem. First, he remembers his own economically poor state at the time of his children's infancy, and lets them leave for the Alps. Plus, the speaker remembers the first words that he now perceives as the only gifts he bestowed on them. After all, the writer of the poem perceives himself as a maker of words. He grapples with the present loss through the memory of a cry for help by his son that occurred years earlier; the speaker is helpless, because he cannot change the situation. He can only accept the present grief and the guilt. He ponders, and hopes that they may have heard his profession of love. Furthermore, the speaker feels like he was blinded by cold feelings, by the snow that represents lost emotions.

Also, there is the symbolic opening of a door by his son in another country, a country of the past, long lost to both. Here the speaker imagines the boy as a giant, his own "Sam-son". It is a metaphor that honors the author's son. This in turn puts the reader in consubstantiality with the author whose real life son was named "Sam." In addition, the speaker (created by the author through his act of writing) remembers the loss of his son in the context of years before his actual death, as he left with his mother and stepfather. “[H]e [Robert Bly] was Sam's stepfather-I'm the natural father” (Ray, E-mail) [5]. The scene of the insurmountable Alps looms large and frigid. It is hard to surmount the cold mountain. Furthermore, the cardboard box may symbolize the boxes we all create, boxes that are hard to escape. The author shoved his daughter along; he felt the loss then and now.

The poem "How to Be Loved" is an ironic dialogue between the lost son and his father. The speaker remembers a scene by the lake "where beneath pine panels/Sam caught ...[him] reading How to Be Loved,/a popular paperback, and asked...[him]/what it said (he never had that trouble)" (1-4) [9]. Here we have the speaker who is reading 
by the lake rather than playing with, or talking to his son. Looking back, the speaker may feel some guilt or regret about this, about lost time he could have spend differently.

Main thing, I said, is never care-People will not love a man who cares, who shows he sadly needs that love. Insouciance is best. And Samuel Cyrus laughed. "Let's get this straight", he said. "You're reading a book called How to Be Loved that says the main thing is not to care, and you care enough to read it. I guess I love you anyhow"... (5-13) [9].

The speaker remembers this conversation between himself and his son and knows that he wasted precious time reading about love while Sam, at that moment near the lake, gave him the love he needed. In memory the speaker knows that Sam had been wiser. Unlike the speaker, Sam "went out to swim...install/an old radio in...[his] Plymouth Valiant" (13-15) [9]. The son performed some actions of physical nature. These were the actual actions of love, rather than the second-hand removed experience of reading about it. Naturally, the reader can only experience this action through reading, because of the symbolic act of writing by the author. The author, who chose some images deliberately, created certain symbols deliberately. For example, the reader can only know what the speaker tells him/her. Poetry, even when it is highly autobiographical is a construct, a fiction, a conscious choice of symbols for effect. The most skilled authors, like David Ray, give the reader images that will help him/her become consubstantial with him, for "Ray writes with a lyrical clarity and assurance that draws us [readers] into wanting to know what he has to say on virtually anything..." (qtd. Gery, Midnight) [10]. For example, the make and model of the car may be such a deliberate choice. The author himself may or may not have owned this particular car. After all, there is a differentia between the author and speaker in the construct/fiction of the poem itself. After all, the author/agent strives for the ideal in relationship to the reality of the loss (act) of the son. He wants the reader to see Sam as valiant, because the author tries to find a resolution and just like the "major emphasis of Burke's work deals with the purification of guilt... Burke uses Dante's Divine Comedy to describe the purification process, ..." the author wants to overcome the grief (Carpenter) [7]. Unlike the speaker's advise in the poem, the author cannot pretend not to care, he cares deeply.

\section{The Author and Motivation}

Plus, in this book the poems are carefully ordered and seem to tie together through different locales (scenes), which can be interpreted as varying states of mind of the speaker. So far, this reader/critic has visited the Opera, the Alps and the lake. The first is a place where high/stylized drama rules. The second scene is a geographically elevated place. The third a place often associated with the life-giving force of water. All these are powerful indicators of symbolic action. Furthermore Burke states: "If action is to be our key term, then drama; for drama is the culminative form of action...But if drama, then conflict...Dramatism is always on the edge of this vexing problem, that comes to culmination in tragedy..." (Burke, From Language 1347) [8].

Next we move to an other country, we are "In Greece" where the speaker and his 
family "ignore the barbed wire/from an old war (1-2) [9]. The speaker remembers the time spent in this country and tries to ignore this leftover sign of war. This poem has powerful symbolic images that convey the intentions of the author. It juxtaposes images of war with those of peace. For in many ways the author fights for a resolution, a resolution that will eliminate the grief.

The donkeys bray all night. My son is the first man to see the holy moon, the wrinkled sea that will shipwreck noSt. Paul tonight not in this lovely cove, calm though the rocks protrude sharp as knives for a martyr. "It's the right moon", Sam says. He is my friend. (3-11) [9].

The speaker states that he will ignore the barbed wire, this symbolizes that he tries to reach some peace. Peace that he strives for in the beautiful surroundings of the cove. The cove that should protect him from the rocks that nevertheless push against him, weigh him down, even in this scene. Moreover, the author chose this poem for inclusion in Sam's Book because of the images portrayed within them, because this particular poem had been written (1968) and published before Sam's death. Therefore, it becomes a symbol intentionally chosen to illustrate the author's attitude/motivation.

The Creation, as the ground or scene of human acts, provides the basic conditions utilized by human agents in the motions by which they act. In this sense it represents an ultimate source of motives, though human agents by their acts may pile up lesser novelties...partial creations which they interpose between themselves and the ultimate ground...a scene having motivational properties in its own right. (Burke, Motives 69) [6].

The image of the wrinkled sea suggests that it is ancient and the son sees the holy moon. The martyr could be likened to the scapegoat, "the song of the scapegoat" which is tragedy (Burke, From Language 1347) [8]. After all, the country is Greece, the place where Western civilization began. Also, a place of the ancient myths, myths that will not be able to sway the speaker because no Saint will be shipwrecked, he will not be moved from his course.

Furthermore, he "lift[s] him high, so high. /A few flowers survive" (14-15) [9].

After Sam's death these last lines probably took on a different meaning for the author. He holds his son in high regard and the important flowers/memories will live. For "[i]t is a principle of drama that the nature of acts and agents should be consistent with the nature of the scene" (Burke, Motives 3) [6] After all, David Ray himself likens writing to a spiritual search (Garmon 5) [1].

Next we are again in a different country, we are in Italy, and "Calabria" is yet an other poem, written when Sam was a toddler (1967), which the author deliberately chose for inclusion in Sam's Book. Now, the scene is presented in the country of the Re-naissance, the country of re-birth. Likewise, the theme of war and peace is present.

"I do feel a sense of responsibility to put everything I feel into a poem. It's not a popular position, not diplomatic...I feel it is a calling, what Quakers call a leading. We serve posterity and nature...” (qtd. in Garmon 7) [1].

Just like in "Greece" the speaker is highly aware of tensions between the America of 
the Vietnam War Era and the rest of the world, even when writing about his family. "David Ray co-founded with Robert Bly the American Writers Against the Vietnam War, and together they edited A Poetry Reading Against the Vietnam War" (Youree 2-3) [4]. Also, this gives a glimpse of the struggle within him that wants to find peace, resolution. It is a strong motivator for this symbolic act of writing for catharsis.

Nobody loved us, not enough to beg us to stay. Is that why we wound up in Calabria? At night we sat by the fire and the beaming, ruddy old woman, bandana on hair, shared out her wine, was proud of her Americans. What a catch we were to break bread with-young couple who busted her bed... (1-8) [9].

The speaker professes that the family was not loved, he feels like an exile, and this sense of profound aloneness has always been part of the creator of the speaker. "I began writing as a teenager, with no thought of why. It was just to express pain and perplexity...[And] I am still vulnerable to-absolute anomie and loneliness, the sinking, despairing feeling that such a gulf exists between individuals that we can rarely cross into the land of Thou instead of It" (qtd. in Garmon 5) [1]. Nobody is a strong affirmation of this loneliness in a place that is not home. The speaker feels unloved even though he has physical closeness to his young wife. However, even though nobody loved them in America this metic woman shared her home. Furthermore, we have the symbolic image of breaking bread. All these are constant reminders of the author's spiritual search for his lost son.

The old woman even loved his "boy Sam/who stood naked in the basin and our girl/bella come unangelo. I'd walk in sun/through hills..." (9-12) [9]. Here the speaker expresses his gratitude for this love because the woman compares the beauty of his daughter to an angel, and she loves his son, unlike everyone in America. The woman "in the little Posta told me anew/Nobody loved us, niente..." (17-18) [9]. It appears that the speaker never received any mail, mail he wished for:

...we hugged, vowed to love one another and those two so small, committed to us. Fireworks shook fields, distant hills, echoes of wars coming near. (23-26) [9].

By choosing to include this poem the author created a metaphor between the actual Vietnam war and the war within himself, the war against the grief over his own profound loss experienced years later. Plus, here we again have an image of fire, just like the ancient fireflies in the poem "At the Opera". However, this image carries with it more violence, more struggle. Furthermore, there is a strong symbolic connection between the wrinkled sea "In Greece" which implies antiquity and the ancient fireflies. It supports Burke's statement about symbolicity, which is quoted on page three of this analysis. Also, both poems, "In Greece" and "Calabria" include water images. The first has the vast ocean and the other a basin for washing. Here we have symbols of water like in "How to Be Loved", which has a lake, in effect we have life force symbols of cosmic and personal implications. Additionally, all these images point to the life of Sam, which was torn, like an explosion of fireworks, from the author. All of this combines to the Metaphor of Loss. "Heartbreaking poems...praise the cycle of life, acknowledge the power of death and express the love of a father for his son" states Andy Brunner in the New York Times Book Review (qtd. Reviews Compilation) [11]. 
Next, let's move on back to a scene in America, which includes symbols of this culture just like in "How to Be Loved". "In the Third Month" we have "his [Sam's\} blue Toyota" (3) [9]. It begins with:

First snow wet against the windshield. I drive by the storefront where we found his blue Toyota. How he loved that car-put fur upon the dashboard to cover cracks-then he and his girl devotedly stretched leather across the back seat making a love nest. (1-6) [9].

The snow is an image of coldness just like the one of the frigidness in the Alps. The speaker remembers his son, his loss as he passes the location where he found the car. However, this time it is a blue Toyota, unlike the Plymouth Valiant in the "How to Be Loved" poem. The color blue may have been chosen deliberately by the author as a symbol to indicate the mood of the speaker. Furthermore, here is an other scene of physical love, parallel to the physical love scene imagery of the speaker and his young wife in the "Calabria" poem. However, in the former it is an image of a broken bed, here it is a cozy nest. Here is the ideal. After all, the flaws have been painstakingly hidden away.

And they went out to Western Auto and bought a little fan... (7-8) [9]

It is an American image, but it also mentions the west, the west that symbolizes death. "Three months after his son's death, the author is... 'simply doing errands...' [nothing] special, but suddenly 'the tears pour down/as I think how much he wanted to be a man'... This 19 line poem is a powerful expression of a father's love for his dead son," states Jack Coulehan (1).

It continues with "later/his fireside books, those I still have,/saved too long to pass on-The Way/of All Flesh, A Shropshire Lad, Don Quixote,/and one stamped in gold but with all pages blank" (15-19) [9]. The writer picked powerful, suggestive titles for this poem. Each symbolizes so much, especially the title about the fleeting flesh. It seems that the author begins to find some resolution here. "I write to cathect pain. All happy poets are alike, every unhappy poet is unhappy in his/her own way...Butler...: The happy man leaves no record. Happiness is consumed with the moment the troubled soul leaves his trail [even] if it's only the slime of a caterpillar going round and round a jar" (qtd. in Garmon 5) [1]. The troubled soul works with the memory. Also, the author used "to be" several times in this collection and it automatically brings forth Shakespeare's famous line. Humans are the symbol users.

Next, we end up "Between Alp and Sea" where the speaker prepares "for the great blow [for the loss]/but did not know it/had simply driven/the old car up the mountain road, afraid/of the abyss..." (1-4) [9]. Here, the automobile is simply an old car. It isn't important because it doesn't reflect on the lost son. Also, the speaker may feel like an old vehicle himself. It is an often used image, especially by those raised in American society. Furthermore, there is a certain consubstantiality with Burke's abyss.

The speaker thinks that his "death...might come at any moment,/the fall, fire, the scorched body, the hell of being alone..." (5-7) [9]. Here the speaker's struggle is clearly evident. It also reveals that the writer is in a struggle, for he included strong spiritual imagery. It continues: 
...I strolled the village, had coffee in the Square, then found a private ledge to view what stone age man had walked to, many a dawn-blue valley cut by river, silvered far below-lazy scene at work, unmaking stone, unmaking Alps, creating France. And that stone age man out from the cave to squat, had left clear word for me, along with the view he loved...

...and son you thought safe over the sea, Oh happy happy son. (8-19, 20-1) [9].

Here just like in the "Greece" poem we have the ever-symbolic images of the sea and stones. Stones cannot feel, they outlast any fleeting human life. Also, here the speaker refers to the unmaking Alps. However, through this unmaking there is creation. There is a strong reference to life. It keeps repeating itself. The speaker also refers to the obviously lost son as happy, meaning that maybe the speaker thinks that he is in a happier realm, while he still remains among the stones. Also, the author chose to include the place (the sea in France) where Sam died. "The poet as a poet makes a poem; and his ways of making the poem are practices which implicitly involve principals...The critic...seeks to make these implicit principles explicit. But he my not be wholly equal to the task-whereupon other critics may arise...” (Burke, Language 33) [12]. This reader/critic finds this statement encouraging because, for example, it was hard to even choose the poems for analysis. However, there is a bit more space in the scene of this analysis.

Just like in the washbasin in "Calabria" with its personal life symbol, in "At the Washing of My Son" the water is used as a cleansing symbol [9]. Furthermore, this time the author includes Mother Superior in his spiritual search. A telling symbol of the Western world.

I ran up and grabbed your arm, the way a man on a battlefield would recognize a long-lost comrade...

Covered with your mother's blood, and I saw that navel where you and I were joined to her. I stood by the glass and watched you squeal. Just twice in a man's life there's this

Scrubbing off of blood. And this holy. Rite that Mother Superior in her white starched hat Was going to deny me. But I stood my ground. (1-2, 6-12) [9].

At this point the speaker is full of determination. He is not going to be denied by a woman who would never bring forth actual life. The "white starched hat" implies rigidity, an adherence to tradition, a tradition the writer had no use for. Furthermore, here is the symbolic use of blood, which like water is essential to human life. Also, here is the blood of birth, and the blood of death, for life is a battle.

Next, in "The Snapshots" there is the ever-present memory, which fills with regret.

Had we known these few images were all we'd have of you we'd have been taking pictures all the time.

The one I need to forget...is the one in my mind without looking. (1-6, 8-9) [9].

The picture that is edged in the unforgiving memory cannot be forgotten. And, this memory is also visible in "Ghosts" where the speaker's memory cannot eliminate the empty space, the loss. For the author writes "for and about...[his] lost son...[and writes] for an abstract but very present face... [that he calls] Der Verstegner [sic] or Understan- 
derer" (qtd. in Garmon 6) [1].

Not ghosts but simply that forever you won't quite know there is not a presence...in sky or stone or evergreen and anywhere you walked together. (1-3, 14-15) [9]

Finally, there is the never-ending speaker of the witness which continues on. It has the ephemeral blood of human life and the enduring stones/burdens of that life.

Laughter cannot wash blood off stones.

Centuries are required.

And rains... (1-5) [9]

Here is the image of water yet again. Maybe the rain of implied tears, because Sam's Book is an homage, an epideictic text that acknowledges the loss through the spiritual search of the author/agent. This search is expressed through the symbolic act of writing, writing expressed through the images in language created from memory. Just like writing is Plato's pharmakon, it is David Ray's drug, a pharmakon that enables him to heal himself, to come to terms with the loss (Neel 66) [13]. Therefore, the writing of the book was a cathartic act. "I don't know of any other book in American literature like it" acknowledges Robert Bly (qtd. Sam’s Book Cover) [9].

"Yes, the poems in SAM'S BOOK are in effect the tip of the iceberg in going through grief, the early stages. I was writing for the supposed catharsis you (and Sigmund Freud and Aristotle) mention, as I still do about Sam and other traumas and griefs" (Ray, E-mail) [5].

Furthermore, Roger Mitchell states in Prairie Schooner that he "admire [s] Ray's honesty and directness, but that he should also be able to make poems out of grief...is a tribute to the steely-nerved artist in him...Sam's Book will stand out among books of contemporary poetry" (qtd. Review Compilation) [11]. Therefore, this Symbolic Metaphor of Loss is such a tribute to the author, to his ethos, because "what is possibly more important [than technical mastery of form] is his contribution in the area of substance..." (qtd. Review Compilation) [11]. "Thus he is both joined and separate, at once a distinct substance and consubstantial with another," with the reader (Burke, From Rhetoric 1325) [14].

The Essential Doesn't Change-Samuel Beckett Waiting for Godot [15].

\section{References}

[1] Garmon, J. (2002) An Interview with David Ray. River King Poetry Supplement, 2, 5-7.

[2] Burke, K. (1931) Counter-Statement. 1st Edition, University of Chicago Press, Chicago.

[3] Cohrs, B. Kenneth Burke’s Dramatism. 1-3. 6 December 2002. http://zimmer.csufresno.edu/ johnca/spch100/5-3-burke.htm Coulehan, J. Literature, Arts, and Medicine Database. 1. 2 December 2002.

[4] Youree, B. (2001) Profile with David Ray: "Escaping the Reality of Fragmentation". Potpourri. 13.1: 1-8. http://www.potpourri.org/editor/bios/bio_ray/bio_ray.html

[5] Ray, D. E-mail from the Author. 13 December 2002

[6] Burke, K. (1962) A Grammar of Motives and a Rhetoric of Motives. The World Publishing Company, Cleveland. 
[7] Carpenter, P. (2002) Rhetoric Web Home page.n. pag. Online. Internet. 12 December 2002. Available carpenpa@mbd1.moorhead.msus.edu.

[8] Burke, K. (2001) From "Language as Symbolic Action". The Rhetorical Tradition Readings from Classical Times to the Present. 2nd Edition, Eds.Bizzel, Boston.

[9] Ray, D. (1987) Sam’s Book. Wesleyan University Press, Middletown.

[10] Gery, J. (1988) Midnight Mind Magazine.n. pag. Southern Illinois University Press, Chicago.

[11] Reviews Compilation. 9 December 2002.

Henderson, G. (1995) Kenneth Burke Society Newsletter, X.

[12] Burke, K. (1968) Language as Symbolic Action. University of Clifornia Press, Berkeley \& Los Angeles.

[13] Neel, J. (1988) Plato, Derrida, and Writing. Southern Illinois University Press, Carbondale and Edwardsville.

[14] Burke, K. (2001) From “A Rhetoric of Motives". The Rhetorical Tradition Readings from Classical Times to the Present. 2nd Edition, Eds.Bizzel, Patricia, and Bruce Herzberg. Bedford/St. Martin's, Boston.

[15] Beckett, S. (1982) Waiting for Godot. Grove Press, Inc., New York.

\section{Submit or recommend next manuscript to OALib Journal and we will provide best} service for you:

- Publication frequency: Monthly

- 9 subject areas of science, technology and medicine

- Fair and rigorous peer-review system

- Fast publication process

- Article promotion in various social networking sites (LinkedIn, Facebook, Twitter, etc.)

- Maximum dissemination of your research work

Submit Your Paper Online: Click Here to Submit

Or Contact service@oalib.com 